\title{
Defining Priorities of Management of Investment Attractiveness of the Region and their Consideration in the Framework of Implementing Large Sports Events ${ }^{1}$
}

\author{
Kramin T.V \\ Institute of Economics, Management and Law, Kazan, 420111, Russia \\ Email: kramint@mail.ru \\ Safiullin L.N. \\ Kazan Federal University, Kazan, 420008, Russia \\ Timiryasova A.V. \\ Institute of Economics, Management and Law, Kazan, 420111, Russia \\ Email: timirasova@ieml.ru
}

Doi:10.5901/mjss.2014.v5n18p275

\begin{abstract}
Objective: forming priorities of management of investment attractiveness of the region and their consideration in the framework of implementing large sports events as exemplified by the Republic of Tatarstan Methods: Institutional, cost and systemic approaches were employed in the work, as well as econometric modeling Results: Investment attractiveness of the region is not only viewed in the work as its objective aggregate characteristic, but interests and positions of existing and potential investors are also considered, considering which priorities of development of investment climate of the Republic of Tatarstan are formed. Methods of assessment of the effect of managerial decisions and measures at regional level on investment attractiveness of the region are developed and conformity of the mentioned changes to the chosen priorities of regional investment policy as exemplified by assessment of the effect of Universiade 2013 in Kazan. Academic novelty: priorities of development of investment climate of the Republic of Tatarstan are formed, methods of assessment of the effect of managerial decisions and measures of regional level on investment attractiveness of the region are offered, a number of regression models is built allowing to assess the effect of large regional projects on the investment potential of the region of Russia as exemplified by the Republic of Tatarstan. Practical relevance: The suggested methods are universal and can be applied when assessing any large regional project in Russia, in any of its subjects.
\end{abstract}

Keywords: investment attractiveness of the region, regional investment policy, Universiade, investment potential, investment risks, methods of assessment of investment attractiveness

\section{Introduction}

Investment attractiveness of the region is a prerequisite condition of its wide investment activity and effective of social and economic development of regional economy.

Management of investment attractiveness of the region is a complex task. It is not easy either to assess the effectiveness of managing it in the region. The task is to some extent simplified if we consider the effect of individual measures and managerial decisions on investment attractiveness of the region, or, to be more exact, on a range of specific factors which determine it. The objective of the present work is development of methods of quantitative assessment of the effect of large-scale regional managerial decisions and measures on the level on investment attractiveness of the region as exemplified by assessment of the effect of preparation and hosting World Student Games 2013 in Kazan.

\footnotetext{
1 This work was financially supported by the Russian Humanitarian Scientific Foundation, within the research project \#13-02-00446a
} 


\section{Forming Priorities of Management of Investment Attractiveness of the Region as Exemplified by the Republic of Tatarstan}

While assessing investment attractiveness, it is possible to analyze many macroeconomic indicators, characterizing effectiveness of functioning of regional economy: foreign trade turnover, domestic regional product, volume of industrial production per head, level of capital investment, living conditions of the population, level of consumer prices, level of unemployment, average monthly salary of the population, average housing for the population of the region.

Assessment of investment attractiveness of the region must include assessment of investment attractiveness of the region itself, taking into account regional institutional environment, political situation, level of development of institutes of corporate management, taxation regulations, etc. In addition, in assessment of investment attractiveness of the region it is necessary to consider financial and economic conditions of individual objects of investment: enterprises, industries, other subjects of economic activity.

While studying investment attractiveness of the object of investment, the analysis is basically confined to essential indicators of effectiveness of investment projects and deals, among which are payoff period, internal rate of return, net present value, profitability index.

It is commonly considered that investors, when choosing a region to invest their funds, are guided by its investment potential and level of investment risks, combination of which defines investment attractiveness of the region. Structure of indicators of investment attractiveness of the region is discussed in more detail in [1]. Yet, behavior of each investor is different. The same factors of investment attractiveness present different benefit to different investors, and in this case it is a subjective characteristic.

In this way, raising competitiveness of the region by creating maximally favorable conditions for investment and start-up and development of businesses is one of the most important goals of regional economic policy.

To define strategic guidelines in forming investment attractiveness of the region, we will study opinions of potential and existing investors of the Republic of Tatarstan based on an independent survey of the «PricewaterhouseCoopers Russia» company in April 2011.

According to the survey, factors of competitiveness of the Republic of Tatarstan are [3] (see Pic.1):

1) large potential of consumption growth, existing developed market channels, equal distance from several cities with a million-plus population (this group of factors was noted by over $80 \%$ of polled investors);

2) low salary in the region (noted by about $80 \%$ investors);

3) existing support of large projects on the part of regional authorities, relatively low administrative barriers (about $60 \%$ investors);

4) existing technologically equipped and convenient business grounds: SEZ «Alabuga», technoparks, technopolices, business incubators (noted by over $40 \%$ investors);

5) real willingness of regional authorities to promptly solve problems of investors, keep promises, respond to feedback; openness of authorities in issues of attracting investments (indicated by about $40 \%$ investors).

Of great importance is the fact that about $70 \%$ investors noted a steady tendency of increasing attention on the part of the authorities of the Republic to the issues of investment policy, significant sustainable improvement of investment climate for the last three to five years.

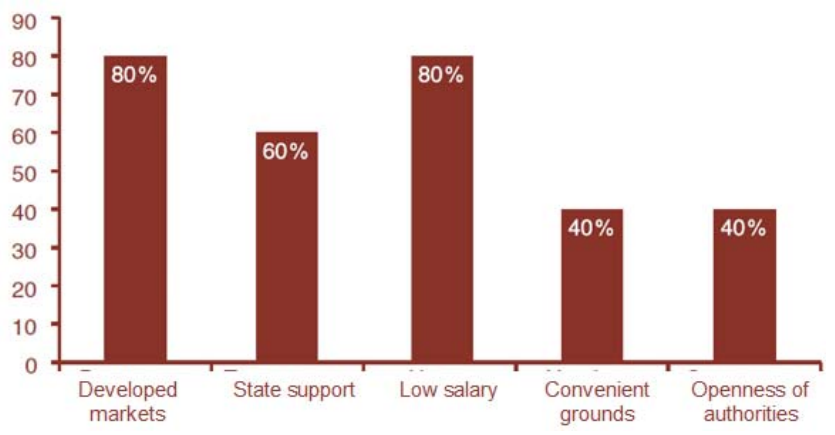

Pic.1. Main competitive advantages of investment in the Republic of Tatarstan in the opinion of investors (in brackets there is the percentage of the polled investors indicating the advantage) [3]. 
Among the main advantages of conducting business in the Republic of Tatarstan, the polled investors named:

1) relatively low level of bureaucracy barriers, no serious problems when registering a business, getting licenses, permissions and approvals received at regional level (90\% investors);

2) tax exemptions for companies implementing investment projects in conformity with the Law of the Republic of Tatarstan «On investment activity» (about 60\% investors).

3) relatively developed infrastructure ( $50 \%$ investors);

4) image of the region; high level of development of petrochemical industry, machinery and construction industry; growing market channels in automobile manufacturing and construction (50\% investors);

5) tax exemptions, customs privileges and commercial benefits for residents of special economic zones (45\% investors);

6) effectiveness of cooperation with the government, in part thanks to «Electronic Government» (20\% investors);

7) interest of the authorities of the Republic of Tatarstan in innovative development of the Republic: creating infrastructure for development of innovation - technoparks and business incubators, holding venture fairs, innovation contests; creating scientific research centers of federal significance, as well as support of a range of innovative production in the Republic.

The first above-mentioned advantage belongs to investment risks, the rest characterize investment potential of the region.

Summing up the opinions of polled investors, we can conclude that difficulties of conducting business in Tatarstan are not significant. Existing difficulties are mostly connected with problems of federal jurisdiction, with development of infrastructure, with peculiarities of education and personnel training. Solution of these problems - in the opinion of investors - is a matter of time. Among the main difficulties of conducting business in Tatarstan most frequently noted are the following:

1) lack of qualified personnel for a number of professions, low level of knowledge of foreign languages (first of all, English), low labor productivity (over 60\% investors);

2) high prices for energy sources and public utilities, high degree of indeterminacy of their dynamics, limitations for gas supply (about 60\% investors);

3) absence of information about the situation in the region, adequate advertising of the region in Europe, poor awareness abroad (about 30\% investors);

4) advanced development of Kazan compared to other regions of Tatarstan in terms of social and transportation infrastructure (about $30 \%$ investors).

During the survey, investors gave their recommendations for defining priorities of development of business and regional investment policy (see Pic.2) [3]:

1) further lowering of administrative barriers, transfer to the «one window» system ( $80 \%$ investors);

2) modernization of transportation system ( $80 \%$ investors);

3) increase of effectiveness of state investment and support of investment projects, use of alternative forms of state participation in support of business ( $75 \%$ investors);

4) further development of social infrastructure (60\% investors).

5) modernization of education and increase of labor productivity ( $40 \%$ investors);

6) expanding measures of support in the area of innovations, encouragement of innovation.

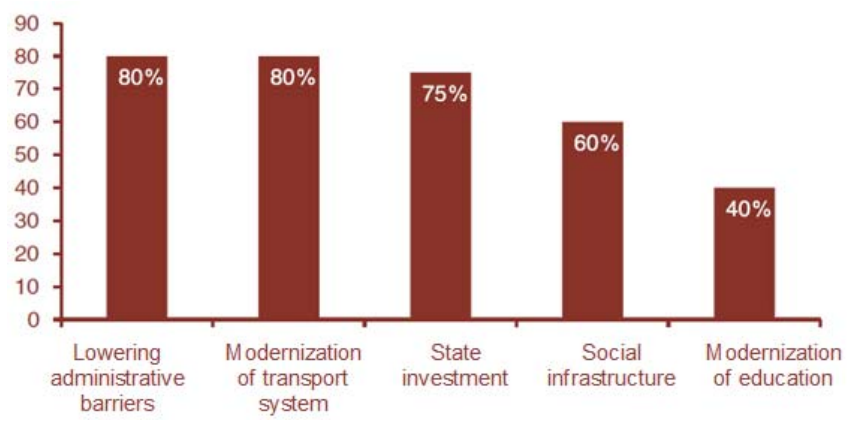

Pic.2. Priorities of development of the Republic of Tatarstan expected by investors 
Effective development of the Republic of Tatarstan in trends corresponding to the above-mentioned priorities is possible in the framework of preparation and hosting summer Universiade 2013 in Kazan.

\section{Realization of Priority Trends of Management of Investment Attractiveness in the Framework of Implementation of the Universiade 2013 Project: Data and Econometric Analysis}

In the present work, the effect of Universiade 2013 in Kazan on investment attractiveness of the Republic of Tatarstan is assessed by a number of trends. [1] has already suggested methods of assessment of raising consumer potential of the Republic of Tatarstan as a result of hosting Universiade 2013 based on econometric modeling. Priority in this work was getting quantitative characteristics of such effect. Sustaining the chosen priorities, the present work suggests development of the mentioned methods for assessment of other factors and components of investment attractiveness of the region as exemplified by the Republic of Tatarstan.

In the process of preparation and hosting Universiade 2013, a number of sports facilities will be constructed, the road traffic and transportation infrastructure of Kazan will be significantly improved (the construction industry will secure a lot of orders), the international image of the Republic will get better, which will give a new impetus to development of tourist industry in the region, growth of consumption in the market of educational services in tourism, trade, hospitality, etc. Significant development of information and communication systems is expected, as well as reforming of institutional environment in the Republic. In terms of the most frequently used structure of investment attractiveness of the region, hosting Universiade 2013 will facilitate growth of financial, consumer, infrastructure and institutional potential of the Republic.

[1] made assessment of raising consumer potential of the Republic of Tatarstan. The influence on consumer potential is assessed based on assessment of growth of potential domestic demand of the population of the Republic as a result of revitalization of industries involved in the preparation of Universiade 2013. We will assess infrastructure potential from the standpoint of its influence on labor productivity in the Republic.

As a result of preparation for Universiade 2013, it is planned to construct and redecorate 64 sporting facilities, consequently, resource-based potential of the region will increase.

Further we will demonstrate how the increasing number of sporting facilities can influence investment attractiveness of the Republic of Tatarstan. Already at present, sports activity of the population of the Republic of Tatarstan significantly increased due to putting into operation of new sporting facilities. A number of research shows that doing sports and fitness reduces infection rate of the population, consequently, labor productivity of working-age population increases, labor potential of the Republic of Tatarstan grows higher. G. Obydennikov shows in his work that the percentage of teaching staff regularly doing sports at one of the Udmurt universities having achieved $31 \%$, and the percentage of those non-regularly doing sports $68 \%$, there appeared to be reduction of infection rate of the mentioned group of employees by $17 \%$ [4].

Table 1. Number of those doing sports and fitness per 1000 people in the Republic of Tatarstan in $2004-2010$.

\begin{tabular}{|l|c|c|c|c|c|c|c|c|c|}
\hline Indicator & 2004 & 2005 & 2006 & 2007 & 2008 & 2009 & 2010 & 2011 & 2012 \\
\hline $\begin{array}{l}\text { Number of those doing sports and fitness } \\
\text { per 1000 people }\end{array}$ & 149,0 & 150,4 & 155,4 & 173,5 & 190,4 & 205,5 & 231,3 & 265,2 & 289,5 \\
\hline
\end{tabular}

We will define the dependence of infection rate of the population of the Republic of Tatarstan on the level of their sports activity. As analyzed indicators, we will consider the number of those doing sports and fitness per 1000 people in the Republic of Tatarstan (indicating it as SPORT) and the number of days of temporary disability of working-age population of the Republic of Tatarstan due to illness (calculated for 100 working people) in $2004-2012$ (indicating it as ILLNESS), data on which are presented in reports of the regional body of the Federal Service for National Statistics for the Republic of Tatarstan (further referred to as Tatarstanstat, see Tables 1, 2) 
Table 2. Dynamics of indicators of temporary disability of working-age population of the Republic of Tatarstan (calculated for 100 working people).

\begin{tabular}{|c|c|c|c|c|c|c|c|}
\hline \multicolumn{8}{|c|}{ cases } \\
\hline & 2006 & 2007 & 2008 & 2009 & 2010 & 2011 & 2012 \\
\hline Total & 57,8 & 63,1 & 60,8 & 62,7 & 60,9 & 57,0 & 55,9 \\
\hline $\mathrm{IL}^{*}$ & 49,6 & 53,7 & 51,9 & 52,9 & 51,1 & 48,3 & 44,9 \\
\hline \multicolumn{8}{|c|}{ days } \\
\hline & 2006 & 2007 & 2008 & 2009 & 2010 & 2011 & 2012 \\
\hline Total & 753 & 789 & 794 & 800 & 793 & 722 & 698 \\
\hline $\mathrm{IL}^{*}$ & 685 & 715 & 720 & 717 & 713 & 651 & 624 \\
\hline
\end{tabular}

* IL - of them by infection rate.

As a result of building a range of econometric models, we got the final version of the regression model including the above-mentioned indicators (see Table 3)

Table 3. Regression model of assessment of the effect of sports activity of the population on infection rate of working-age population in the Republic of Tatarstan.

\begin{tabular}{|c|c|c|c|c|}
\hline Included observation: 7, Sample: 2006 - 2012 & \multicolumn{3}{|c|}{ Dependent variable ILLNESS } \\
\hline Variable & Coefficient & Standard error & t-statistics & Probability of $\mathrm{H}_{0}$ hypothesis \\
\hline C & 860.6757 & 45.97463 & 18.72067 & 0.0000 \\
\hline SPORT(-2) & -1.188807 & 0.274130 & -4.336651 & 0.0123 \\
\hline ILLNESS(-1) & 0.069702 & 0.032263 & 2.160422 & 0.0968 \\
\hline$R^{2}$ & 0.826773 & \multicolumn{2}{|c|}{ F-statistics } & 9.545522 \\
\hline Durbin-Watson statistics & 1.936681 & Probability of null hypothesis by F-statistics & 0.030008 \\
\hline
\end{tabular}

Flash-forwarding more detailed characteristics of the built model, we should sum up the results of regression modeling. As a result of forming the model, it has been proved that growth of sports activity of the population, including physical training, reduces overall time of temporary disability of economically active population due to illness. The mentioned effect happens at a two-year lag (time delay), that is, increasing sports activity of the population in the current year of 2012 will exert reducing effect on infection rate in two years, in 2014. The degree of this effect is quantitatively determined by the parameters of the built model (see below).

The regression model presented in Table 3 is well specified: coefficients at independent variables are statistically significant; value of Durbin-Watson statistics of the model is close to two (which is relevant for regression models built by dynamic series); indicator $\mathrm{R}^{2}$ exceeds $82 \%$, which emphasizes the fact of explaining over $82 \%$ fluctuations of the dependent variable as a result of building the model; the F-statistics value is rather high, and probability of confirming its null hypothesis is less than $5 \%$, which characterizes the common high level of specification of the regression model.

In addition, the outcome of the model corresponds to common sense and results of other research: the model proves that growth of sports activity reduces the number of days of disability of the population. Confirmation of this fact follows due to the negative sign of the coefficient before the independent variable SPORT(-2). In the model presented in Table 3, there are lagged variables. The value of the lag is indicated in brackets after the variable name.

The dynamic series of the ILLNESS variable contains serial correlation. To eliminate it from the model, the model includes the autoregression variable ILLNESS(-1) as explanatory variable. In addition, regression analysis allowed to define the time delay (lag) of the effect of growth of sports activity on infection rate of the population, two time periods (two years) in duration, and as a result, the independent variable SPORT is taken in the model with the lag (-2).

To define contribution of the SPORT variable in explanation of the dynamics of the ILLNESS indicator, we will eliminate the autoregression variable from the model (see Table 4) 
Table 4. Supplementary autoregression model of defining contribution of the SPORT variable in explanation of the dynamics of the ILLNESS indicator

\begin{tabular}{|c|c|c|c|c|}
\hline Included surveys: 6, Sampling 2005 - 2010 & Dependent variable ILLNESS - volume of investment of the Republic of Tatarstan (per year) \\
\hline Variable & Coefficient & Standard error & t-statistics & Probability of $\mathrm{H}_{0}$ hypothesis \\
\hline C & 861.6490 & 60.52814 & 14.23551 & 0.0000 \\
\hline SPORT(-2) & -0.961006 & 0.333157 & -2.884544 & 0.0344 \\
\hline $\mathrm{R}^{2}$ & 0.624641 & \multicolumn{2}{|c|}{ F-statistics } & 8.320595 \\
\hline Durbin-Watson statistics & 1.134139 & Probability of null hypothesis by F-statistics & 0.034405 \\
\hline
\end{tabular}

The sought contribution of the SPORT variable in explanation of the dynamics of the ILLNESS indicator illustrated by the indicator $\mathrm{R}^{2}$, equals $62 \%$. Thus, the SPORT variable explains $62 \%$ fluctuations of the ILLNESS indicator.

In this way, regression modeling defined quantitative interconnection between sports activity and labor productivity of working-age population, which is defined by the factor of disability due to illness:

ILLNESS $=861.6490-0.9610 *$ SPORT $(-2)+\varepsilon$,

or

ILLNESS $=860.6757-1.1888 *$ SPORT $(-2)+0.0697^{*} \operatorname{ILLNESS~}(-1)+\varepsilon(1)$,

where $\varepsilon$ - regression equation error

According to the above equation, to forecast the level of disability of working-age population due to illness next year, it is necessary to know the infection rate this year and sports activity last year.

It should be noted that the above results comply well with the results of a similar research we conducted two years ago. The final view of the corresponding equation for $2004-2010$ was [2]:

ILLNESS $=563.2563-0.2500$ * SPORT $(-2)+0.2746 *$ ILLNESS $(-1)+\varepsilon(2)$,

As it is seen from the parameters of the mentioned model, the regression model is quite stable, yet sensitivity of the indicator of infection rate to the level of sports activity in the Republic of Tatarstan grows significantly (see equations (1) and (2)).

In addition, it should be noted that increase of the number of people doing sports by $1 \%$ reduces, other conditions being equal, temporary disability of working-age population of the Republic of Tatarstan for ten days a year, calculated for every 100 working people.

According to the data of the state public institution «Employment centre of Kazan», economically active employed population of Kazan at the end of 2012 makes 609,7 th.people. That is why the above-mentioned (1\%) increase of sports activity of the population in Kazan will lead to reduction of disability due to illness by 60970 person-days a year. So, labor potential of the Republic of Tatarstan will grow without attracting more manpower. In addition, labor productivity of the employed population will increase.

We will assess growth of infrastructure potential as a factor of investment attractiveness of the region. During preparation for Universiade 2013 in Kazan, road traffic and transportation infrastructure was developed. To ensure accessibility of the Universiade facilities, the following objects were constructed: 12 road junctions, 23 city motorways, major repair of 73 city streets totaling $123 \mathrm{~km}, 42$ pedestrian crossings; construction of the first line of Kazan metro totaling $17,3 \mathrm{~km}$ and 10 stations was completed; the air-terminal complex of the international airport «Kazan» was reconstructed.

Development of road traffic and transportation infrastructure in the framework of preparation for the Universiade allowed working Kazan dwellers to save on average 40 minutes during commuting. Conventional working time savings per worker made 165 hours a year (based on 248 working days in 2012). On the whole for Kazan, economically active population can save $94,4 \mathrm{mln}$. man-hours or 11,8 mln. person-days at the minimum, based on 8-hour working day. Using the mentioned released time to implement their employment duties, economically active Kazan dwellers could produce works for the amount of $2108 \mathrm{mln}$.rub. a year, based on 160-hour working month and average salary for Kazan 28,6 th.rub. a month in 2011 (data of the Committee of economic development of Kazan).

Tourist potential of the Republic of Tatarstan as a result of hosting Universiade 2013 must increase significantly. This statement is indirectly confirmed by the results of hosting the Olympic Games in Barcelona - a vivid example of a positive effect of the Games on the development of infrastructure and improvement of tourist potential of the host country (the number of tourist visits to Barcelona increased twice in 2000 compared to 1991). Although huge capital investments into infrastructure made by the authorities of Barcelona were a heavy burden on the city budget, and the budget of Barcelona in late nineties was deficit-ridden, those expenses secured economic growth and development of the city in the long run as a result of decreasing need of the city in investment. In addition, growth of the tourist industry proved positive 
for increase in revenue of the city.

Compared to other subjects of the Volga Federal District, the Republic of Tatarstan possesses a unique tourist and recreational potential. This makes the Republic of Tatarstan an ideal region for development of different kinds of tourism and hospitality industries. Tourism in Tatarstan is one of the most promising areas of social and economic development. For the last five years, the tourist influx to Tatarstan grew 2,5-fold, at the annual average growth rate of $12-18 \%$, making at the end of 2010 about $1 \mathrm{mln}$. people. Volume of provided tourist services in the Republic in 2010 made 5,2 bln. rubles going higher 2,4-fold compared to 2005.

Yet, the tourist potential of the Republic could remain just potential. Success of this international project depends on the work of many people, effectiveness of cooperation of many interested parties in using the legacy of the Universiade. In case events unfold optimistically, total revenue in tourism of the Republic of Tatarstan will make tens of billion rubles during the planning period up to 2020.

\section{Conclusions}

Thus, preparation and hosting summer Universiade 2013 in Kazan potentially significantly increased investment attractiveness of the Republic of Tatarstan. Moreover, noticeable progress is achieved in all priority trends of development of the Republic of Tatarstan indicated by investors in the poll of the «Pricewaterhouse Coopers-Russia» company concerning investment attractiveness of the Republic of Tatarstan in 2011: administrative barriers are lowered; modernization of road traffic and transportation system took place; effectiveness of state investment was enhanced, the range of forms of state support of businesses and innovations broadened; social infrastructure developed further; educational system is to rise to the new level, labor productivity of economically active population increased.

\section{References}

Kramin T. Development of methods of management of investment attractiveness of regions of Russia / T. Kramin, V. Leonov // Actual Problems of Economics and Law. - №1(21), 2012. - P.40-47

Kramin T. Defining priorities of management of investment attractiveness of the region and following them in the framework of implementing large sports events / T. Kramin, V. Leonov // Actual Problems of Economics and Law, Poznanie, Kazan, 2012. №1. P.39-45

Investor's guide Republic of Tatarstan. - www.pwc.ru

Obydennikov G. Forming positive attitude of university teachers to healthy lifestyle / G. Obydennikov // Materials of international virtual scientific and practical conference «Topical issues of pedagogics and psychology», 01.08.2011.

Romanova, A.I. Investment development of construction in the region on the basis of project financing / A.I. Romanova, E.A. Dobroserdova // News KGASU. 2012. - № 4 (22). - S.459-464

Safiullin L.N., Bagautdinova N.G., Safiullin N.Z., Ismagilova G.N. The development of welfare theory in conditions of changes in the quality of goods and services. World Applied Sciences Journal. 2012. T. 18. № SPL.ISSUE. 18. 144-149 pp. 
